\title{
Gallbladder Cancer pN1 TNM Finding v8
}

National Cancer Institute

\section{Source}

National Cancer Institute. Gallbladder Cancer pN1 TNM Finding v8. NCI Thesaurus. Code C134658.

Gallbladder cancer with metastases to one to three regional lymph nodes. (from AJCC 8th Ed.) 